\title{
BROILER AND SWINE PRODUCTION: ANIMAL WELFARE LEGISLATION SCENARIO
}

\author{
Raquel Baracat Tosi Rodrigues da Silva ${ }^{1}$; Irenilza de Alencar Nääs²*; Daniella Jorge de \\ Moura $^{2}$ \\ ${ }^{1}$ UNICAMP/FEAGRI - Programa de Pós-Graduação em Engenharia Agrícola. \\ ${ }^{2}$ UNICAMP/FEAGRI - Lab. de Conforto Térmico/Construções Rurais e Ambiência, C.P. 6011 -13083-970 - \\ Campinas, SP - Brasil \\ *Corresponding author <irenilza@agr.unicamp.br>
}

\begin{abstract}
Brazil is the world largest meat exporter and one of the most recent demands of the import market is directed towards animal welfare. Codes, norms and legislations used in Brazil are out of date, and in most cases those adopted for both poultry and swine production are based on international standards to meet trade requirements. This research aimed to study and describe an overall scenario of the standards, norms and legislations for animal welfare items applied to broiler and swine production: rearing, handling and transportation. The critical points of these items were identified in accordance to standards and current literature on animal welfare issues, effective on January 2008. The comparison was based on given scores varying from 1-5 (very bad to very good) as function of the existence of standard norms and legislations for each country and/or economic block, and for each type of demand, as well as the level of adoption by producers. When compared to counterparts Brazil detained the lowest score for all types of demands, and its mean score of norms is lower $(p<0.05)$. For both poultry and swine production the European Union provides detailed information to producers, followed by Australia and United States. Exception is made to standards in moving or transporting swine within the farm. Brazilian legislation for poultry production presents a general insufficiency of $58 \%$, while in swine production the highest deficit is in transportation. There is a need to invest in updating animal welfare standards, norms and legislation in the country for maintaining its international competitiveness.
\end{abstract}

Key words: animal production, rearing, transportation, environment, norms

\section{PRODUÇÃO DE FRANGOS DE CORTE E SUÍNOS: CENÁRIO DALEGISLAÇÃO SOBRE BEM-ESTARANIMAL}

\begin{abstract}
RESUMO: Brasil é o maior exportador de carne e uma das mais recentes importantes demandas do mercado importador está em torno do bem-estar animal. Os padrões, normas e legislações usadas no país são desatualizadas e, em muitos casos, estas são seguidas na produção animal são baseadas em padrões internacionais, para seguir requisitos do comércio que não atendem necessariamente o esquema brasileiro de alojamento. Esta pesquisa objetivou estudar e descrever o cenário das normas e legislações para as seguintes exigências, aplicadas a produção de frango de corte e suínos: alojamento, manejo e transporte, para subsidiar normas adequadas aplicadas às condições nacionais. Os pontos críticos destes itens foram identificados de acordo com padrões, normas de bem-estar animal e com a literatura vigente até Janeiro de 2008. A comparação foi baseada em escores atribuídos variando de 15 (muito ruim até muito bom) como função da existência de padrões, normas e legislações para cada país e/ou bloco econômico e para cada tipo de exigência, com relação ao nível de relevância adotada pelos produtores. Quando comparado com seus pares, o Brasil deteve o menor escore para todos os tipos de exigência e o escore médio de normas brasileiras é baixo $(p<0,05)$. Para produção de aves e suínos a União Européia detém mais detalhes em informações de produção seguida da Austrália e dos Estados Unidos. Com exceção de padrões em movimentação ou transporte de suínos dentro da fazenda. A legislação brasileira para produção de frangos de corte apresenta deficiência geral de 58\%, enquanto na produção de suínos a maior deficiência está no transporte. Há necessidade de se investir em melhora nas normas e legislações de bem-estar animal no país.

Palavras-chave: produção animal, alojamento, transporte, ambiente, normas
\end{abstract}

\section{INTRODUCTION}

World meat consumption is nearly $40 \mathrm{~kg}$ per capita year $^{-1}$ and in developing countries it increased from 14 to 30 since the eighties (FAO, 2006; USDA, 2005). Poultry and swine production in Brazil has high de- 
gree of mechanization and control of operations, and the export market includes countries such as Russia, Canada, Japan, China, the Arabian countries and the European Union (Boni \& Paes, 2000; Nääs \& Mantovani, 2002; USDA, 2005). Due to consumer demands and afterwards reinforced by governmental regulation in some regions, and further on by private certification agencies, the demands towards animal welfare have increased along with other issues related to international trade, such as children labor and sustainable agricultural production (EUREPGAP, 2005; European Commission, 2006; Horne \& Achterbosch, 2008).

Even though the primary role of farm animals is for human food consumption, and the level of inputs such as feed, housing, disease control and environment management has reached a high degree of technology, the production process has been pushed to its biological limit and there is an increasing challenge to meet animal well-being, or yet human-perceived welfare (Dawkins, 2003; McInerney, 2004). Handling procedures, stocking density, free access to feed and water, adequate housing and air quality are well documented and have been regulated in several countries (Albright, 1990; Boivin et al., 1992; Silva, 2001; Wathes et al., 2002; Pawelek \& Croney, 2003; Moura et al., 2006; Romanini et al., 2008). Comprehensive knowledge of farm animal behavioral activities is important for the improvement of animal husbandry, and related information has been used for establishing appropriate directives and legislations for animal welfare worldwide (Duncan et al., 1991; Brüninghaus, 1993; Snowdon, 1999; Puma et al., 2001; Dawkins, 2003; Wechsler, 2005). Brazilian legislation does not specifically address animal welfare issues and producers involved in the international meat export market rely on standards and information found in codes of good practices published by extension and research institutions (Brasil, 2001; Dias, 2000; Amaral et al., 2006; Avila et al., 2007), on international private certification agencies (EUREPGAP, 2005), and in current available literature (Silva, 2000; Cony \& Zocche, 2004; Aradas \& Nääs, 2005; Tolon \& Nääs, 2005).

This research aimed to build up an overall scenario for broiler and swine welfare by comparing codes, norms and legislations, in which the largest world meat producing countries were evaluated, using a set of international trade recommendations.

\section{MATERIALAND METHODS}

Legislation from three countries (Brazil, Australia and the United States of America, USA) and an economical common market (European Union, EU) as well as standards, norm and instructions from certification and accreditation, state and private institutions (DEFRA and EUREPGAP) were analyzed.

Since welfare of animals is not a simple concept. It needs to be analyzed in a wide range of identified outcomes. It can vary according to the levels by which human perception would judge it, within a certain range varying from "bad" (low welfare standard) to "excellent" (high welfare standard). In most countries the status of the welfare codes which specify aboveminimum standards are at present advisory rather than compulsory, as it is not yet clear if a declared choice of policy should be made in the general (rearing conditions) or specific grounds (teeth and tail cutting and beak trimming) of welfare standards. Furthermore, since the public good aspect of animal welfare is absolute (as if it effectively decreases the value gained from the livestock product when not met), the eventual economic sanctions against failing to meet the minimum established standards need to be sufficient (generally not due to several reasons, among them the economic) to detain any producer from taking the risk of seeking non-welfare productivity gains (McInerney, 2004).

In absence of laws and directives whose application needs to be either advisory or compulsory, any existing norms were considered as guidance to be adopted by producers, and although in a voluntary basis, they were taken into account in this specific research, as existing regulation. Due to the increasing consumer demands, welfare international codes have been evolving considerably over time, focusing on the identification of the boundaries of public interest to underline the increment treated as ethics. Facing this restrain, it was necessary to establish a timeline for this present scenario; so, the reviewed references were considered up to March 2008.

Numerous educational, assessment and certification programs have been lately created and marketed to ensure transparency, creditability and accountability for the methodologies utilized for farm animals. They differ in specific statements but there are common points which were taken into account, and were the most representative for the meat trade demands were then selected, according to the available knowledge (Duncan et al., 1991; Snowdon, 1999; Puma et al., 2001; Dawkins, 2003; Pawelek \& Croney, 2003).

Two species in production were selected for the study, broiler chicken (G. gallus domesticus) and swine ( $S$. domesticus), considering their rearing under average local conditions. Poultry production was taken into account from the first day of rearing to the day the flock was harvested and transported to slaughter. Swine production was studied starting in the growing towards the finishing phases. 
The main provision of Directive 2007/43/EC is to reduce the animal stocking density by setting a maximum value, for instance broiler density up to $39 \mathrm{~kg}$ $\mathrm{m}^{-2}$ (European Commission, 2007). The Directive also sets standards covering other housing conditions such as lighting, litter, feeding and ventilation requirements. Due to the warm climate, Brazilian and Australian farmers keep broilers at a relatively low stocking density of approximately $35 \mathrm{~kg} \mathrm{~m}^{-2}$ distinct from growers at USA, and this lack of uniformity was the reason that stocking density was not evaluated in this study. It was assumed that the housing environment would point towards a broad view of rearing issues, which are well defined under international trade codes for both poultry and swine production.

Broilers - The most common issues involving problems found in broiler production were considered, related to three specific topics: transportation (from hatchery to farm and from farm to slaughter); management (beak trimming, rearing and feeding); and housing environment (heat stress, ammonia concentration and noise level).

Swine - Critical points for achieving good welfare degree were considered in: transportation (within the farm and from farm to slaughter); management (castration, rearing and feeding); and housing environment (heat stress, ammonia concentration and noise level). Certain specific welfare items were not analyzed such as: early weaning; and piglet tail cutting and teeth trimming.

Scores were given to each specific demand in relation to its requirement in international codes, in a range of 1 to 5 , where each value was related in accordance to the EUREPGAP (2005) norms such as: 1 $=$ very bad (there is no norm regarding this subject when compared to the international standards), $2=\mathrm{bad}$ (there are few norms and few or none for compliance), $3=$ average (there are norms for at least half of those in the international standard), $4=\operatorname{good}$ (there is a great deal of norms and regulations regarding several events during production and a good degree of compliance), $5=$ very good (codes and regulations agree totally with the international norms and there is a high degree of compliance). The obligation of following a specific legislation or norm was not considered, but rather the presence of descriptions, details or measurements concerning each selected management or procedure.

Tables were built using the criteria described above, and the average of the scores was calculated both for the specific type of demand and for each evaluated country and economic block, in order to verify and quantify how much they depart from or agree with the international trade codes on the selected animal well-being issues. Since welfare is a complex theme combining both subjective and objective aspects of animal life quality, the scores were granted based on the existence of specific norms that addressed solely to the selected items.

Comparative analysis of the mean score values was used for evaluating the performance of each country or economic block in terms of addressing the welfare legislation for both broiler and swine production, regarding the chosen types of demand. The software Minitab (2005) was used for the statistical analysis at a confidence interval of $95 \%$.

\section{RESULTS AND DISCUSSION}

The following resultant scenario was described based on the operational decisions about animal welfare, settled around the setting and implementation of standards on the threshold limit. This is due to the implication of the policy objective of adopting "higher" welfare standards, which is is not relevant until the necessary norms are universally put into practice.

Broiler - The comparative score scenario between Brazil, European Union, Australia and the United States of America with respect to the welfare normative demands in poultry production indicates that Brazilian norms are highly lacking in addressing this issue (Table 1).

Both transportation scenarios are rarely discussed in the scientific literature resulting in few facts that may subsidize codes or regulations; besides, the way of transporting animals may vary from one country and region to others, as well as the use of specific designed trucks. The text of the European Commission (2007) points out the transportation on roads as an important issue to be under a specific directive; as well as the material in EUREPGAP (2005) has a special chapter that addresses the way the workers apply the fasting restrictions prior to slaughter.

Because the EU states generally adopt the mandatory directives, which are somehow similar to the norms suggested by EUREPGAP (2005), the corresponding score in this field was high (3.5 and 4.0 respectively). The score given to the USA was 3.0 due to the lack of specific legislation, and Australia got 3.5 as the country adopts legislation that has specific topics regarding this matter, although lacking in details. In both the USA and Australia the adoption of the norms is voluntary.

Low score was given to Brazil (1.0 and 1.5) as the legal background of this topic does not go beyond the mention that the birds need to be handled carefully, not stating any specificity in this procedure. Grandin 
Table 1 - Comparative scores on welfare demand in broiler chicken production norms considering international standards for European Union (EU), Brazil, Unites States of America (USA) and Australia.

\begin{tabular}{|c|c|c|c|c|c|}
\hline Type of demand & EU & Brazil & USA & Australia & Average \\
\hline \multicolumn{6}{|l|}{ Transportation } \\
\hline From the arrival to rearing (WF) & 3.5 & 1.0 & 2.5 & 3.5 & 2.6 \\
\hline From farm to slaughter (FS) & 4.0 & 1.5 & 3.0 & 4.0 & 3.1 \\
\hline \multicolumn{6}{|l|}{ Management } \\
\hline Beak trimming $(\mathrm{BT})$ & 4.0 & 1.5 & 3.5 & 4.0 & 3.2 \\
\hline Rearing $(\mathrm{R})$ & 4.5 & 2.5 & 4.5 & 4.5 & 4.0 \\
\hline Feeding $(\mathrm{F})$ & 4.0 & 3.0 & 4.0 & 4.0 & 3.7 \\
\hline \multicolumn{6}{|l|}{ Housing environment } \\
\hline Ammonia concentration (AC) & 4.5 & 3.5 & 4.0 & 4.5 & 4.1 \\
\hline Heat stress (HS) & 4.0 & 3.0 & 3.0 & 4.0 & 3.5 \\
\hline Noise level (NL) & 2.5 & 1.0 & 2.0 & 2.0 & 1.8 \\
\hline Average & 3.8 & 2.1 & 3.3 & 3.8 & \\
\hline
\end{tabular}

Transportation: From the arrival to rearing (WF); From farm to slaughter (FS). Management: Beak trimming (BT); Rearing (R); Feeding (F). Housing environment: Ammonia concentration (AC); Heat stress (HS); Noise level (NL).

(1997) and Freeman (1988) enhance the meaning of having specific norms regarding the handling and transportation, since neglecting them may compromise flock's or herd's overall well-being.

Araújo et al. (2005) and Pizzolante et al. (2007) found that birds were not subjected to beak trimming present more aggressiveness, and there is larger feed ration loss when compared to trimmed birds. This subject is addressed in the Brazilian norms related to breeders, recommending being careful about trimming but not indicating how the procedure needs to be done, thus the given score was 2.0. Legal normative texts are published in the USA regarding the beak trimming procedure, even though in a fuzzy way, and because of that the score was set as 3.5. Both in Australia and in the European Union there are specific norms regarding broiler breeder beak trimming, thus the given score in this item was 4.0 , as specific management for the trimming is not fully stated.

Rearing condition is well discussed in the norms and legislations of developed countries as it is an issue responsible for high mortality in the flock; however, published knowledge on this matter still did not convert into Brazilian norms (Aradas \& Nääs, 2005; Araújo et al. 2005; Tinôco \& Gates, 2005; Miragliotta et al, 2006). Because of that a score of 2.5 was credited to Brazil, while the USA, Australia and the EU were given the score of 4.5, as the content of their current legislations present more detailed information and are quite similar. Both feeding systems and nutrition are well discussed in Brazilian literature (Silva, 2000); however, this knowledge has also not yet been converted into norm or published as a good practice guidance (Avila et al., 2007). Thus the score given to Brazil in this subject was 3.0. Both Australia and the USA have specific norms dealing with this matter in terms of feeding access, nutrition and the amount of serving, and for that their given scores were 4.0.

As for the housing air quality the current literature states limits for ammonia concentration and even though there is available national publication on this subject, it lacks in specific knowledge of the impact on broiler production under specific conditions (Ogilvie et al., 2000; Miragliotta et al., 2002). That led to qualify Brazil with a score of 3.5. The USA, Australia and the EU adopt specific norms and legislation indicating levels of tolerance and ways of mitigation of gas exposure, and thus their score were 4.0 (due to less information when compared to the other two), 4.5 and 4.5 respectively. Heat stress has been well discussed in literature over the last twenty years including data under tropical and sub-tropical housing (Albright, 1990; Curtis \& Backstrom, 1992; Cony \& Zocche, 2004; Aradas \& Nääs, 2005). However, neither in Brazilian nor in the USA norms was included, leading to a score of 3.0 for both countries. The EU followed by Australia established norms with detailed rearing temperature limits as well as limits for heat stress exposure, thus their given scores were 4.5. Animal noise level exposure was not clearly addressed in the normative texts and the given score for this topic for Brazil was 1.0, while for both the EU and the USA it was 2.5 , and for Australia it was 2.0 due to proportional information on available current codes. Considering all types of studied demands the average score of Brazil regarding broiler production welfare norms was significantly below the mean score of the studied counterparts $(2.1 ; p<0.05)$. 
The scenario of Brazilian norms and legislations for broiler production compared to its counterpart countries and economic block (USA, Australia and EU) shows that there is not a significant difference $(p<$ 0.05 ) between norms and legislations related to the demands of heat stress, feeding management and general rearing conditions adopted in Brazil and other countries/economic blocks (Figure 1). Regarding ammonia concentration, noise level, beak trimming and transportation to rearing there was a significant difference between the groups $(p<0.05)$. For transportation from farm to slaughter Brazilian codes of good practices lack in detail and content, and they were below average $(p<0.05)$.

Calculating the mean score value of the remaining poultry meat producers and comparing them to Brazil it was found that this country only meets nearly $58 \%$ $(p<0.05)$ of the highest level of trade demand which is applied the private certification institution EUREPGAP (2005).

Swine - Swine welfare is a multidimensional concept and its assessment includes resource-based and animal-based measures such as stereotypic behavior, space allowance and air quality inside housing, for determining on-farm risk factors concerning the provision of resources, as well as management, stockmanship and farm characteristics. Based on these factors the scores were given to the selected countries and economic blocks (Table 2).

Due to the detail of information in directive instructions the EU was given the score of 3.0 for the transportation within the farm although lacking in details on handling of the animals; and 4.0 for the transportation from farm to slaughter as it addresses up to fasting time and forms of transportation (Brüninghaus, 1993; Waterhouse, 1996; European Commission, 2005). Australia was given the same scores as the country adopts norms that are very similar to the European directives in this subject. Even though there is available literature on swine welfare issues, Brazilian codes of good practices are weak in addressing specific transportation issues, thus the given score was 1.0 and 1.5 for both transportation aspects (Chagnon et al., 1991; Tolon \& Nääs, 2005). The USA scores (3.0 and 4.0) partially follow the norms described in EUREPGAP (2005), although lacking in specific details such as waiting time prior to slaughter.

Regarding rearing conditions the EU establishes quite high standards based on the available specific literature towards swine rearing under particular climate conditions, and for this the given score was 4.5 (Cossins \& Bowler, 1987; Rinaldo \& Le Dividich, 1991). In Brazil producers rely on limited information from technical textbooks that are informative, and due to this the given score was 3.0. In Australia specific mandatory legislation has been developed specifically to feeding strategies which led to the given score of 4.0, as well as the USA where producers generally follow the international norms in voluntary way. As the EU normative has straight agreement with the EUREPGAP (2005) towards feeding and drinking water strategies such as spacing, amount of feeding and drinking water quality, the given score was 4.5. Rinaldo \& Dividich (1991) and Brown-Brandl et al. (1998) show that both feeding and drinking management are directly related to the animal well-being and may induce loss in production when neglected. In Brazil the producers are led by code of good practice textbooks (Amaral et

Table 2 - Comparative scores on welfare demand norms in swine production considering international standards for European Union (EU), Brazil, Unites States of America (USA) and Australia.

\begin{tabular}{|c|c|c|c|c|c|}
\hline Type of demand & EU & Brazil & USA & Australia & Average \\
\hline \multicolumn{6}{|l|}{ Transportation } \\
\hline Inside the farm (WF) & 3.0 & 1.0 & 3.0 & 3.0 & 2.5 \\
\hline From farm to slaughter (FS) & 4.0 & 1.5 & 4.0 & 4.0 & 3.3 \\
\hline \multicolumn{6}{|l|}{ Management } \\
\hline Rearing (R) & 4.5 & 3.0 & 4.5 & 4.0 & 4.0 \\
\hline Feeding $(\mathrm{F})$ & 4.5 & 3.5 & 4.0 & 4.0 & 4.0 \\
\hline \multicolumn{6}{|l|}{ Housing environment } \\
\hline Ammonia concentration (AC) & 4.5 & 3.0 & 4.0 & 4.5 & 4.0 \\
\hline Heat stress (HS) & 4.0 & 3.0 & 4.0 & 4.0 & 3.7 \\
\hline Noise level (NL) & 4.0 & 2.5 & 3.9 & 3.9 & 3.5 \\
\hline Average & 4.1 & 2.5 & 3.9 & 3.9 & \\
\hline
\end{tabular}

Transportation: Within the farm (WF); From farm to slaughter (FS). Management: Rearing (R); Feeding (F). Housing environment: Ammonia concentration (AC); Heat stress (HS); Noise level (NL). 
al., 2006) in which the items are mentioned with limited details or limits, thus the given score was 3.5. The USA producers voluntarily adopt codes with more detailed instructions, and the given score for this item was 4.0.

Housing environment has well established standards and norms in developed countries specially with respect to heat stress exposure and ammonia concentration; however, ventilation issues and the whole environmental scenario is not completely described in the EU directives (score 4.5), while in Brazil producers have codes of good practices indications (score 3.0), and in the USA farmers voluntarily adopt partially the equivalent to the EU standards (given score 4.0). Australia producers follow norms very close to the EU directives, besides accessing the producers more detailed text material, had a given score of 4.5 .

Ammonia concentration may be harmful to pigs in the early age which leads to bad welfare (Sobestiansky et al., 1991; Takai et al., 1998; Wathes et al., 2002; Queiroz et al., 2005; Sampaio et al., 2007). Housing dimensions and rearing conditions are well addressed in the literature and subsidize international legislation (Cossins \& Bowler, 1987; Rollin, 1995; Grandin, 2000). Australia, the EU and the USA point the limits in the current norms; however, they lack in detailed information regarding heat stress exposure and ventilation issues (score 4.0). In Brazil producers voluntarily adopt codes of good practice textbooks although they do not address limits (score 3.0).

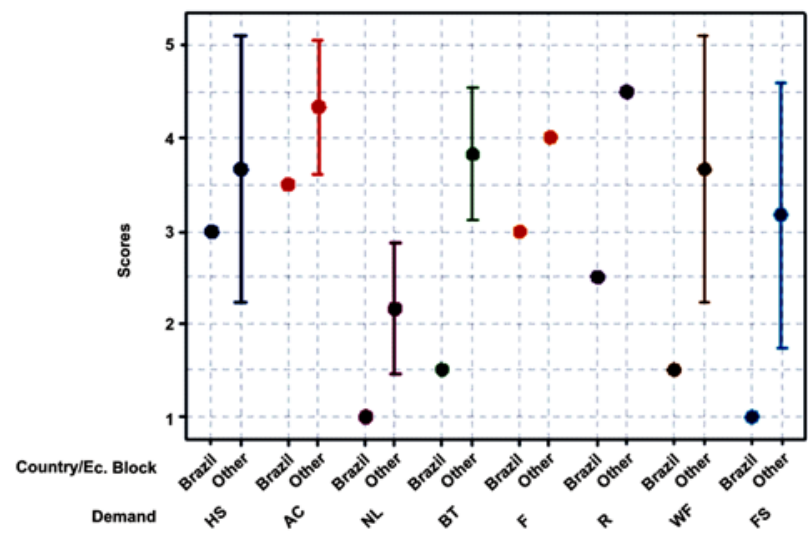

Housing environment: Heat stress (HS); Ammonia concentration (AC); Noise level (NL). Management: Beak trimming (BT); Feeding (F); Rearing (R). Transportation: From the arrival to rearing (WF); From farm to slaughter (FS).

Figure 1 - Comparison between the scores of Brazil and the other countries and economic block (Australia, USA and $\mathrm{EU}$ ) for broiler chicken production welfare norms and legislation.
When comparing all scores for swine production it was found that there was no variation between available norms in Australia, the USA and the EU ( $p$ $<0.05$ ) for all types of demands, and they had higher standard than in Brazil (Figure 2). No difference was found in the group $(p<0.05)$ for the demands of heat stress, feeding and transportation from farm to slaughter. Considering ammonia concentration and rearing, difference $(p<0.05)$ was found between the scores related to the presence of norms and legislation in Brazil, when compared to the other counterparts.

Transportation within the farm, understood as the moving of animals from a building to other during the production cycle, was the item Brazil had the lowest score $(p<0.05)$. However, the other countries and economic block states somehow neglect partially this issue.

Animal welfare concerns described in the recent EU normative should not motivate trade restrictions on imports of both poultry and swine products from developing countries into the EU (European Commission, 2007; Horne \& Achterbosch, 2008). However, the European Commission has defined strong ambitions for improving animal welfare in the EU and its trading partners, and is subsidizing discussions on animal protection within the World Organization for Animal Health (OIE) which is accepted under the World Trade Organization (WTO) agreement as the body that sets the standards on animal health issues in global trade, and has established a working group on animal welfare. Although the WTO has not explic-

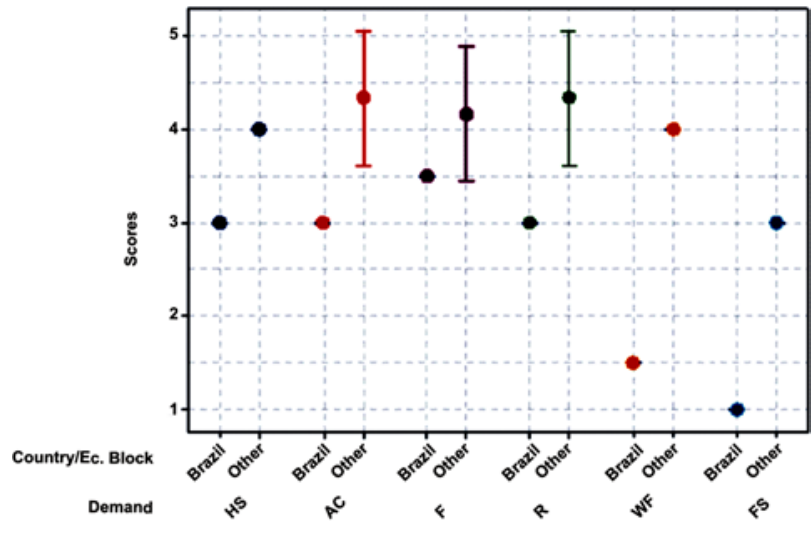

Transportation: Within the farm (WF); From farm to slaughter (FS). Management: Rearing (R); Feeding (F). Housing environment: Ammonia concentration (AC); Heat stress (HS); Noise level (NL).

Figure 2 - Comparison between the scores of Brazil and the other countries and economic block (Australia, USA and EU) for swine production welfare norms and legislation. 
itly recognized animal welfare as a legitimate cause for impeding trade, the EU has advocated this issue on the agenda for international negotiations. On the other hand, the member countries of OIE agreed on developing general guidelines for animal welfare in relation to slaughter, transportation and killing of animals for disease control purposes (OIE, 2004). For the coming years, even though desired, it cannot be expected that the OIE will promptly provide comprehensive global standards on animal welfare at the farm level, and this will leave the meat production countries without specific international guidance other than recognized specific directives or codes of good practices.

The fact remains that higher standards of animal welfare are highly related to consumer's personal choice and possibly dominated by income level, education, and awareness. Further, the overall adoption of such rules is directly associated with simple and definable features of animal production systems, that can be widely recognized by consumers and presented explicitly, and certifiable as product characteristics.

\section{CONCLUSIONS}

A scenario was built for comparing the adoption of farm welfare norms of meat exporting countries and economic blocks, by imputing a subjective scoring system. Among the compared meat producer countries Brazil seized the lowest overall score for both broiler and swine production, meaning that the country has the opportunity to develop or adopt norms which are adequate to its specific rearing and economical conditions, for better competing in the international meat trade.

\section{ACKNOWLEDGEMENT}

To CNPQ (National Council for Scientific and Technological Development) for the scholarship and research grant.

\section{REFERENCES}

ALBRIGHT, L.D. Environmental control for animals and plants. St. Joseph: ASAE, 1990. 455p. (Textbook, 4).

AMARAL, A.L.; LIMA, G.J.M.M.; SILVEIRA, P.R.S.; KLEIN, C.S.; PAIVA, D.P.; MARTINS, F.; KICH, J.D.; ZANELLA, J.R.C.; FÁVERO, J.; LUDKE, J.V.; BORDIN, L.C.; MIELE, M.; HIGARASHI, M.M.; MÓRES, N.; DALlA COSTA, O.A.; OLIVEIRA, P.A.V.; BERTOL, T.M.; SILVAL, V.S. Boas Práticas de produção de suínos. Concórdia, 2006. Available at: www.cnpsa.embrapa.br/sgc/sg c publicacoes publicacao_k5u59t7m.pdf. Accessed 10 Jan 2009.

ARADAS, M.E.C.; NÄÄS, I.A. Thermal environment in broiler houses using two bird densities under tropical conditions. Agricultural Engineering International, v.7, p.1-10, 2005.
ARAÚJO, L.F.; CAFÉ, M.B.; LEANDRO, N.S.M.; JUNQUEIRA, O.M.; ARAÚJO, C. S.S.; CUNHA, R.; SILVA, C.C. Desempenho de poedeiras comerciais submetidas ou não a diferentes métodos de debicagem. Ciência Rural, v.35, p.169-173, 2005.

AVILA, V.S.; KUNZ, A.; BELLAVER, C.; PAIVA, D.P.; JAENISCH, F.R.F.; MAZZUCO, H.; TREVISOL, I.M.; PALHARES, J.C.P.; ABREU, P.G.; ROSA, P.S. Boas práticas de produção de frangos de corte. Concórdia, 2007. Available at: www.cnpsa.embrapa.br/ $\mathrm{sgc} / \mathrm{sgc}$ publicacoes/publicacao s8t285e.pdf. Accessed 10 Jan 2009.

BOIVIN, X.; LE NEINDRE, P.; CHUPIN, J.M. Establishment of cattle-human relationships. Applied Animal Behaviour Science, v.32, p.325-335, 1992.

BONI, I.J.; PAES, A.O.S. Climatização de aviários: aquecimento e refrigeração para matrizes In: CURSO SOBRE EQUIPAMENTOS AVÍCOLAS PARA O SETOR DE CORTE, São Paulo, 2000. Resumos. São Paulo: Serviço Nacional de Aprendizagem Industrial, 2000. p.47-65.

BRASIL. Lei n. 9605, de 12 de fevereiro de 1998. In: Gomes, L.F. Constituição Federal: código penal, código de processo penal. 3 ed. São Paulo: Editora Revista dos Tribunais, 2001. p.1248.

BROWN-BRANDL, T.M.; NIENABER, J.A.; TURNER, L.W. Acute heat stress effects on heat production and respiration rate in swine. Transactions of the ASAE, v.41, p.789-793, 1998.

BRÜNINGHAUS, B. Die Stellung des tieres. Berlin: Humbolt, 1993. 148p.

CHAGNON, M.; D'ALLAIRE, S.; DROLET, R. A prospective study of sow's mortality in breeding herds. Canadian Journal of Veterinary Research, v.55, p. 180-184, 1991.

CONY, A.V.; ZOCCHE, A.T. Manejo de frangos de corte. In: MENDES, A.A.; NÄÄS, I.A.; MACARI, M. Produção de frangos de corte. Campinas: FACTA, 2004. cap.8, p.118136

COSSINS, A.R.; BOWLER, K. Temperature biology of animals. London: Chapman \& Hall, 1987. 325p.

CURTIS, S.E.; BACKSTROM, L. Housing and environment: influence on production. In: LEMANN, A.D.; STRAW, B.E.; MENGELING, W.L.; D'ALLAIRE, S.; TAYLOR, D.J. Disease of swine. Ames: Iowa State University Press, 1992. p.884-900.

DAWKINS, M.S; COOK, P.A.; WHITTINGHAM, M.J.; MANSELL, K.A.; HARPER, A.E. What makes free-range broiler chickens range? In situ measurement of habitat preference. Animal Behaviour, v.66, p.1-10, 2003.

DEPARTMENT FOR ENVIRONMENT, FOOD AND RURAL AFFAIRS - DEFRA. 2007. Available at: www.defra.gov.uk/ search/. Accessed 22 Aug. 2007.

DIAS, E.C. A tutela jurídica dos animais. Belo Horizonte: Mandamentos, 2000. p. 155.

DUNCAN, I.J.H.; PETHERICK, J.C. The implications of cognitive processes for animal welfare. Journal of Animal Science, v.69, p.5022-5071, 1991 .

EUREPGAP. The global partnership for safe and sustainable agriculture. Available at: http://www.eurepgap.org/Languages/ English/index html. Accessed 16 Nov. 2005.

EUROPEAN COMMISSION. Report. Communication to the Council and Parliament on the experience acquired by MemberStates since the entry into force of Directive 95/29/EC of the Council changing Directive 91/628/EEC on the protection of animals during transport. Available at: http://europa.eu.int/ comm/food/. Accessed 29 Sept. 2005.

EUROPEAN COMMISSION. Commission working document on a Community Action Plan on the Protection and Welfare of Animals 2006-2010: Strategic basis for the proposed actions. Available at: http://ec.europa.eu/food/animal/welfare/ index en.htm. Accessed 18 Dec. 2007a.

EUROPEAN COMMISSION. Commissioner Kyprianou welcomes Council agreement on animal welfare rules for broilers. Press Release IP/07/630, May 8. Available at: http://ec.europa.eu/food/ animal/welfare/index en.htm. Accessed: 18 Dec. 2007b. 
FOOD AND AGRICULTURE ORGANIZATION - FAO. Report 2006. Rome: FAO, 2006. 24p. Available at: www.faostat.faooorg. Accessed 02 Oct. 2006.

FREEMAN, B.J. The domestic fowl in biomedical research: physiological effects of the environment. World's Poultry Science Journal, v.44, p.44-60, 1988.

GRANDIN, T. Assessment of stress during handling and transport. Journal of Animal Science, v.75, p.249-257, 1997

GRANDIN, T. Perspectives on transportation issues: the importance of having physically fit and cattle and pigs. Journal of Animal Science, v.79, p.201-207, 2000.

HORNE, P.L.M. van.; ACHTERBOSCH, T.J. Poultry welfare and EU standards. World's Poultry Science Journal, v.64, p.4051,2008

McINERNEY, J. Animal welfare, economics and policy: report on a study undertaken for the farm \& animal health economics. Londres: DEFRA, 2004. 68p.

MINITAB versão 15.1.0.0. Belo Horizonte: Global Tech, 2005.

MIRAGLIOTTA, M.Y.; NÄÄS, I.A.; BARACHO, M.S.; ARADAS, M.E.C. Qualidade do ar de dois sistemas produtivos de frango de corte com ventilação e densidade diferenciadas: estudo de caso Engenharia Agrícola, v.22, p.1-10, 2002.

MIRAGLIOTTA, M.Y.; NÄÄS, I.A.; MANZIONE, R.L.; Nascimento, F.F. Spatial analysis of stress conditions inside broiler house under tunnel ventilation. Scientia Agricola, v.63, p.426-432, 2006.

MOURA, D.J.; NÄÄS, I.A.; PEREIRA, D.F.; SILVA, R.B.T.R.; CAMARGO, G.A.V. Animal welfare concepts and strategy for poultry production: a review. Brazilian Journal of Poultry Science, v.8, p.137-147, 2006.

NÄÄS, I.A.; MANTOVANI, E.C. Trends in mechanization in livestock production in Brazil. Agricultural mechanization in Asia, Africa and Latin America, v.33, p.56-60, 2002.

OGILVIE, J.R.; BARRY, D.A.; GOSS, M.J.; STONEHOUSE, D.P. Balancing environmental and economic concerns in manure management by use of an on-farm computerized decision support systems. In: INTERNATIONAL SYMPOSIUM ON ANIMAL, AGRICULTURE AND FOOD PROCESSING WASTES, 8., Des Moines, 2000. St. Joseph: ASAE, 2000. p.460-467.

PAWELEK, R.; CRONEY, D. Understanding and addressing issues related to the well-being of livestock. 2003. Available at: www.eesc.regonstate.edu. Accessed 20 Jul. 2007.

PIZZOLANTE, C.C.; GARCIA, E.A.; SALDANHA, E.S.P.B.; LAGANÁ, C.; FAITARONE, A.B.G.; SOUZA, H.B.A.; PELICIA, $\mathrm{K}$. Beak trimming methods and their effect on the performance and egg quality of Japanese quails (Coturnix japonica) during lay. Brazilian Journal of Poultry Science, v.9, p.17-21, 2007.

PUMA, M.C.; XIN, H.; GATES, R.S.; BURNHAM, D.J. An instrumentation system for studying feeding and drinking behaviour of individual poultry. Applied Engineering in Agriculture, v.17, p.365-374, 2001.

QUEIROZ, M.P.G.; NÄÄS, I.A.; SAMPAIO, C.A.P. Estimating thermal comfort for piglets considering ammonia concentration. Agricultural Engineering International, v.7, p.1-10, 2005.

RINALDO, D.; LE DIVIDICH, J. Influencie de la temperatura ambiente sur les performances de croissance du porc. Producion Animale, v.4, p.57-65, 1991.
ROLLIN, B.E. Farm animal welfare: social, bioethical, and research issues. Ames: Iowa State University Press, 1995. 168p. ROMANINI, C.E.B.; TOLON, Y.B.; NÄÄS, I.A.; MOURA, D.J. Physiological and productive responses of environmental control on housed sows. Scientia Agricola, v.65, p.335-339, 2008.

SAMPAIO, C.A.P.; NÄÄS, I.A.; BARACHO, M.S.; SALGADO, D.D. Avaliação de poluentes aéreos em instalações de creche e terminação de suínos. Ciência Rural, v.37, p.25-32, 2007.

SILVA, I.J.O. Ambiência na produção de aves em clima tropical. Jaboticabal: SBEA, 2001. v.1, p.67-87. (Série Engenharia Agrícola e Construções Rurais).

SILVA, R.G. Introdução à bioclimatologia animal. São Paulo: Nobel, 2000.

SNOWDON, C.T. O significado da pesquisa em comportamento animal. Estudos de Psicologia, v.4, p.365-373, 1999.

SOBESTIANSKY, J.; MARTINS, M.I.S.; BARCELLOS, D.E.S.H.; SOBRAL, V. B.G.M. Formas anormais de comportamento dos suínos: possíveis causas e alternativas de controle. Concórdia: EMBRAPA-CNPSA, 1991, 29p. (Circular Técnica, 14).

TAKAI, H.; PEDERSEN, S.; JOHNSEN, J.O.; METZ, J.H.M.; GROOT KOERKAMP, P.W.G.; UENK, G.H.; PHILLIPS, V.R.; HOLDEN, M.R.; SNEATH, R.W.; SHORT, J.L.; WHITE, R.P.; HARTUNG, J.; SEEDORF, J.; SCHRÖDER, M.; LINKERT, K.H.; WATHES, C.M. Concentrations and emissions of airborne dust in livestock buildings in Northern Europe. Journal of Agricultural Engineering Research, v.70, p.59-77, 1998.

TINÔCO, I.F.F., GATES, R.S. Ambiência e construções para matrizes pesadas. In: MACCARI, M.; MENDES, A.A. (Ed.) Manejo de matrizes de corte. Campinas: FACTA, 2005. cap.2, p.11-33.

TOLON, Y.B.; NÄÄS, I.A. Avaliação de tipos de ventilação em maternidade de suínos. Engenharia Agrícola, v.25, p.565574, 2005.

UNITED STATES DEPARTMENT OF AGRICULTURE - USDA. Foreign Agricultural Service Report: commodity and marketing programs. livestock and poultry world markets and trade. Washington: D.C.: USDA/FAS, 2005. 25p. Available at: http:// www.fas.usda.gov/dlp/dlp.html. Accessed:13 Nov. 2006.

WATERHOUSE, A. Animal welfare and sustainability of production under extensive conditions: a European perspective. Applied Animal Behaviour Science, v.49, p. 29-40, 1996.

WATHES, C.M., JONES, J.B.; KRISTENSEN, H.H.; JONES, E.K.M.; WEBSTER, A.J.F. Aversion of pigs and domestic fowl to atmospheric ammonia. Transactions of the ASAE, v.45, p.1605-1610, 2002.

WECHSLER, B. An authorization procedure for mass-produced farm animal housing systems with regard to animal welfare. Livestock Production Science, v.94, p.71-79, 2005.

WORLD ORGANIZATION FOR ANIMAL HEALTH - OIE. Report of the Third Meeting of the OIE Working Group on Animal Welfare. Paris, 2004. Available at: www.oie.int. Accessed 20 Aug. 2008.

Received December 18, 2007

Accepted June 10, 2009 